\title{
Upaya Peningkatan Keterampilan Berbicara Menggunakan Media Gambar Siswa Kelas IV SD
}

\author{
Elwi Nailul Muna ${ }^{1}$, I Nyoman Sudana Degeng ${ }^{2}$, Fattah Hanurawan ${ }^{3}$ \\ ${ }^{1}$ Pendidikan Dasar-Universitas Negeri Malang \\ ${ }^{2}$ Teknologi Pendidikan-Universitas Negeri Malang \\ ${ }^{3}$ Psikologi-Universitas Negeri Malang
}

\begin{tabular}{l}
\hline \hline INFO ARTIKEL \\
\hline Riwayat Artikel: \\
Diterima: 14-06-2019 \\
Disetujui: 18-11-2019 \\
\hline
\end{tabular}

\section{Kata kunci:}

speaking skill:

image media;

elementary school student;

keterampilan berbicara;

media gambar;

siswa sekolah dasar

\begin{abstract}
ABSTRAK
Abstract: This research aims to know the use of picturemedia to improve speaking sklills and to know the students speaking ability after using the picture media. The results of the study are as follows. First, by applying the picturemedia, it can improve students spakng skills. After the research was conducted, it looks that students can communicate in communicative, sort, and correct way. Second, by applying a picture media on the process of learning to improve students speaking skills, can be seen that there is an improvement on the score result on speaking skills, from 28 students, $82 \%$ (23 students) have got a score above minimum score, that is $75 \%$.

Abstrak: Penelitian ini bertujuan untuk mengetahui penggunaan media gambar untuk meningkatkan keterampilan berbicara dan mengetahui kemampuan berbicara siswa setelah menggunakan media gambar. Hasil penelitian tersebut sebagai berikut. Pertama, dengan menerapkan media gambar dapat meningkatkan keterampilan berbicara siswa. Hal ini terlihat bahwa setelah dilakukan penelitian tindakan kelas, siswa dapat berkomunikasi secara komunikatif, urut, baik, dan benar. Kedua, dengan menerapkan media gambar pada proses pembelajaran guna untuk meningkatkan keterampilan berbicara siswa dapat terlihat bahwa terdapat peningkatan pada hasil nilai keterampilan berbicara terlihat dari 28 siswa, $82 \%$ (22 siswa) telah mencapai ketuntasan minimal yaitu $75 \%$.
\end{abstract}

\author{
Alamat Korespondensi: \\ Elwi Nailul Muna \\ Pendidikan Dasar \\ Universitas Negeri Malang \\ Jalan Semarang 5 Malang \\ E-mail: elwiunmuh.073@gmail.com
}

Proses pembelajaran didalamnya terlibat antar anggota kelas. Interaksi yang terjalin harus bagus selama proses pembelajaran berlangsung. Kegiatan pada pembelajaran yang ada sebuah bakat berbahasa siswa salah satunya. Sejalan dengan pernyataan (Tarigan, 2015) bahwa keterampilan dalam berbahasa memiliki empat komponen, yaitu menyimak, berbicara, membaca, dan menulis. Salah satu keterampilan yang memiliki peran penting dalam menciptakan sebuah proses pembelajaran yang aktif dan kreatif yaitu keterampilan berbicara. (Tarigan, 1992) menyampaikan bahwa berbicara merupakan keterampilan yang menggunakan cara untuk mengeluarkan ekspresinya melalui bahasa lisan. Hal tersebut juga sama seperti (Cullinan, 1993) yang berpendapat bahwa berbicara memiliki pengaruh dalam kurikulum seni bahasa secara keseluruhan, bicara juga diperlukan pada semua mata pelajaran karena menjadi sarana utama yang digunakan siswa untuk bereksplorasi mengenai hubungan yang diketahui dan pengamatan yang baru ditemui. Keterampilan berbicara merupakan hal yang paling mendasar dalam penggunaan pada setiap situasi dan tujuan. Artinya, biasanya siswa di Sekolah Dasar berbicara di sekolah dengan tujuan untuk dapat menceritakan dirinya sendiri, pengalamanya, atau apa yang ada di sekitarnya. Hal ini sesuai dengan taraf yang ada pada perkembangan siswa tingkat SD.

Berbicara merupakan keterampilan yang paling penting dan esensial, penguasaan dalam keterampilan ini menggambarkan tentang pembicara yang memiliki pengetahuan yang lebih tepat. Pencapaian kompetensi keterampilan berbicara pun juga dapat membantu siswa untuk menunjang keterampilan yang lainnya seperti baca dan tulis. Keterampilan siswa bicara dapat jauh lebih memudahkan penyimaknya dalam mendengarkan apa yang sedang dibicarakan. Selain itu, diperkuat dengan pendapat yang dikemukakan oleh (Hedge, 2008) mengenai kegiatan yang jauh membantu lebih baik dalam keterampilan berbicara adalah kegiatan diskusi dan bermain peran. Kegiatan tersebut juga dapat meningkatkan aktivitas siswa dalam berbahasa. 
Berdasarkan Kurikulum 13 pada Sekolah Dasar kelas IV semester II khususnya aspek berbicara berfokus pada kemampuan yang dimiliki anak bicara dengan baik. Kemampuan berbicara siswa yang baik menjadi suatu penentu keberhasilan siswa dalam pemahamannya selama mengikuti proses pembelajaran. Di saat siswa memiliki kemampuan berbicara yang kurang maka siswa tersebut sulit paham akan materi selama proses pembelajaran sehingga hasil belajar yang dimiliki siswa akan cenderung rendah dalam terampil berbicara. Sejalan dengan pendapat (Wilson, 1997) menyatakan bahwa keterampilan berbicara, seperti komunikasi yang baik antar siswa memang diperlukan model, jika dimodelkan akan berperan sebagai pendorong siswa untuk berbicara dengan orang yang ada di sekitarnya, baik siswa yang lain maupun dengan gurunya secara akademis maupun sosialnya. Hal yang dapat dilakukan seperti membuat situasi dalam kelas menjadi jauh lebih kondusif.

Berdasarkan pengamatan proses pembelajaran yang dilakukan pada tanggal 22 Februari 2019 di kelas IVB SD Muhammadiyah 1 Malang khususnya pembelajaran berbicara, siswa diberikan tugas untuk menceritakan kembali cerita fiksi yang ada pada buku siswa dengan menggunakan bahasanya sendiri. Terdapat beberapa siswa yang diberikan kesempatan untuk maju di depan kelas dan menceritakan kembali cerita yang sudah dibaca di buku siswa, sedangkan anak berpendapat berkesempatan maupun bertanya mengenai bacaan pada buku siswa. Namun, nyatanya masih banyak siswa yang kurang berhasil mendapatkan nilai yang masih cukup rendah dan dibawah rata-rata. Dari pengamatan tersebut terlihat ada beberapa faktor yang memengaruhi ketidakberhasilan siswa dalam terampil berbicara. Terlihat dari cara siswa tersebut dalam berekspresi di depan kelas masih terlihat ragu-ragu, ada ketakutan, dan rasa malu ketika diberikan kesempatan untuk maju di depan kelas. Masih banyak siswa yang tidak mau mencoba untuk maju didepan kelas atau pun mengajukan pertanyaan maupun pendapatnya mengenai cerita yang ada di buku siswa yang diceritakan kembali menggunakan bahasanya sendiri. Tidak hanya itu ada beberapa faktor lain yang mendasari seperti guru yang masih monoton dalam menyampaikan materi pembejaran, pembelajaran kurang inovatif dan kreatif, kurang menariknya penyampaian materi pembelajaran, belum adanya penggunaan media pembelajaran, pemahaman murid yang masih rendah, serta interaksi yang terjadi antara guru dan siswa masih kurang terjalin baik. Materi pembelajaran masih banyak berpusat pada guru sehingga murid merasa bosan selama proses pembelajaran berlangsung. Guru masih menitikberatkan pada metode ceramah dalam penyampaiannya sehingga murid jauh lebih pasif selama pembelajaran.

Proses pembelajaran dapat jauh berjalan lebih efektif, anak di dalam kelas juga terlihat jauh lebih antusias serta secara tidak langsung dapat menumbuhkan rasa percaya diri yang ada pada diri siswa. Hasil penelitian yang diperoleh dari upaya dalam meningkatkan keterampilan berbicara dengan menggunakan media gambar dapat terlihat bahwa interaksi yang terjadi antara guru dengan siswa dalam menjawab pertanyaan, bercerita di depan kelas, menceritakan dengan menggunakan bahasanya sendiri, menceritakan pengalaman sendiri yang dimiliki anak mulai meningkat. Berdasarkan data yang sudah dipaparkan di atas maka peneliti melakukan penelitian tindakan kelas yang bertujuan untuk menyelesaikan permasalahan yang ada.

\section{METODE}

Penelitian ini menggunakan pendekatan kualitatif dan kuantitatif dengan jenis penelitian deskriptif dan rancangan Penelitian Tindakan Kelas. Peneliti menjadi pengamat partisipan dalam penelitian ini. Lokasi yang digunakan untuk penelitian yaitu di SD Muhammadiyah I Malang yang beralamat di Jl. Kawi No.7 Kota Malang Jawa Timur. Data yang digunakan dalam penelitian ini berupa paparan deskripsi mengenai keterampilan berbicara yang dimiliki siswa yang dikumpulkan secara kualitatif. Teknik pengumpulan data yang digunakan, yaitu hasil belajar, observasi, wawancara, dan dokumentasi. Pada observasi peneliti sebagai pengamat peristiwa yang terjadi selama proses pembelajaran berlangsung. Pada wawancara peneliti sebagai pengumpul data dengan melakukan tanya jawab kepada guru dan siswa mengenai permasalahan yang ada di dalam kelas yang dilakukan secara tidak terstruktur. Pada dokumentasi, peneliti sebagai pengumpul data setiap kegiatan keterampilan berbicara untuk membuktikan berlangsungnya proses pembelajaran dengan mendokumentasikannya.

Penelitian tindakan kelas ini menggunakan siklus model (Kemmis \& MC, 2014), pada setiap siklus tindakannya yang dilaksanakan terdiri atas empat tahapan, yaitu perencanaan, tindakan, pengamatan, dan refleksi. Teknik analisis yang digunakan yaitu perhitungan rata-rata kelas, ketuntasan belajar, dan hasil belajar siswa. Fokus penelitian yang digunakan pada penelitian ini berupa upaya dalam peningkatan siswa dalam terampil bicara memakai media gambar.

\section{HASIL}

Deskripsi hasil kegiatan yang dilaksanakan berdasarkan siklus yang digunakan selama tindakan dari penilaian dan pengamatan selama proses pembelajaran. Subjek penelitian yang digunakan sebanyak 28 siswa kelas IVB SD Muhammadiyah 1 Malang terdiri atas 14 siswa perempuan dan 14 siswa laki-laki. Penelitian ini dilaksanakan sebanyak dua siklus. Setiap siklus I terdiri atas tiga kali pertemuan dan siklus II terdiri atas dua kali pertemuan. Kumpulan data pada kegiatan ini yaitu hasil dari kemampuan yang dimiliki guru dalam merencakan, melaksanakan proses pembelajaran, dan peningkatan keterampilan siswa pada siklus I dan II. Pelaksanaan pembelajaran yang digunakan untuk meningkatkan keterampilan berbicara dengan menggunakan media gambar didalamnya. Proses pembelajaran dilakukan pada saat pelaksanaan pembelajaran tematik. Kegiatan pembelajaran yang dilakukan guru diawali dengan memberikan stimulus kepada siswa sebelum memulai pembelajaran. Guru berusaha mengajak siswa ke dalam situasi dimana siswa berada di lingkungan materi yang akan dibelajarkan selama proses pembelajaran. 
Studi pendahuluan yang dilakukan pada saat melakukan proses sebelum adanya tindakan siklus, bertujuan untuk mengamati masalah yang ada dan mengidentifikasi objek yang akan diteliti. Kegiatan pratindakan yang dilakukan yaitu mengamati proses pembelajaran yang didalamnya terdapat unsur-unsur yang dapat meningkatkan keterampilan berbicara seperti kegiatan diskusi, presentasi, maupun pengamatan yang sifatnya ada di luar kelas. Peneliti pada kegiatan pratindakan melakukan wawancara secara terstruktur dengan guru dan tidak terstruktur dengan siswa mengenai aktivitas belajar maupun sejauh mana permasalahan keterampilan berbicara yang ada di dalam kelas. Pelaksanaan kegiatan pratindakan dimulai dengan mengamati proses pembelajaran yang dilakukan didalam kelas. Kegiatan yang dilakukan guru pada kegiatan pratindakan yaitu melaksanakan proses pembelajaran seperti biasanya. Kondisi yang terlihat pada saat melakukan pengamatan, terlihat respons yang diberikan siswa pasif. Minat siswa dalam menerima materi yang diberikan guru masih kurang. Guru pada saat menyampaikan materi masih banyak menggunakan metode ceramah sehingga siswa terlihat bosan selama proses pembelajaran berlangsung. Siswa masih belum aktif didalam kelas, seperti belum ada siswa yang memberikan pertanyaan mengenai pemahaman yang dimiliki setelah guru menanyakan tentang pemahaman materi. Kegiatan diskusi yang dilakukan siswa dan berbicara di depan kelas masih terlihat rendah, hanya beberapa siswa yang mampu menunjukkan kemampuannya berbicara. Pertanyaan yang diberikan siswa yang tidak presentasipun atas dasar ditunjuk oleh guru, hanya sekitar sembilan siswa dari keseluruhan jumlah yang ada di kelas yang mampu memberikan pendapat, pertanyaan maupun kritikan mengenai materi yang dipresentasikan dengan arahan dan beberapa siswa yang ditunjuk guru.

Pelaksanaan pembelajaran yang dilakukan guru hanya menggunakan buku siswa dan lembar kerja dalam menyampaikan materi didalam kelas. Guru sudah menggunakan model pembelajaran, tetapi belum sepenuhnya sintaksnya sesuai dan ada beberapa sintaks yang tidak digunakan oleh guru. Media didalam kelas masih belum digunakan terlebih untuk meningkatkan keterampilan berbicara siswa. Berdasarkan permasalahan tersebut peneliti melakukan pembagian angket kepada siswa untuk mengetahui minat siswa dalam terampil berbicara.

Penilaian yang dilakukan peneliti pada kegiatan pratindakan menunjukkan adanya kekurangan siswa dalam menuntaskan hasil belajarnya dalam berbicara. Pelaksanaan pembelajaran yang belum menggunakan model kooperatif dan media pembelajaran masih menunjukkan nilai yang ingin dicapai yaitu nilai rata-rata secara klasikal mencapai 70 dan persentase ketuntasan belajar mencapai $\geq 75 \%$. Nilai rata-rata yang didapat siswa secara klasikal mencapai 68.86 sehingga perbaikan pembelajaran sangat dibutuhkan untuk meningkatkan keterampilan berbicara khususnya. Nilai rata-rata dan persentase tersebut masih sangat jauh mencapai indikator ketercapaian dalam melakukan penelitian ini yaitu nilai mencapai 70 dan persentase mencapai $\geq 75 \%$. Hal ini yang menjadi dasar peneliti untuk melakukan perbaikan dalam proses pembelajaran khususnya untuk meningkatkan keterampilan yang dimiliki siswa. Sesuai dengan evaluasi yang dilakukan peneliti dan guru, perbaikan pembelajaran dilakukan dengan menerapkan model pembelajaran berbantuan media untuk dapat meningkatkan keterampilan berbicara siswa.

\section{Siklus I}

Hasil penelitian yang dilakukan pada tindakan siklus I berupa proses pembelajaran guna meningkatkan keterampilan berbicara siswa melalui media gambar. Aspek yang diamati pada proses pembelajaran yaitu aspek kebahasaan dan non kebahasaanya. Kegiatan pelaksanaan yang dilakukan pada siklus I, meliputi perencanaan, pengamatan atau pelaksanaan, refleksi, dan perbaikan. Berdasarkan penerapan yang dilakukan pada siklus I, proses pembelajaran yang dilakukan dengan menggunakan alternatif tersebut sudah mampu meningkatkan keaktifan siswa khususnya dalam berbicara. Siswa sudah mulai memberikan respon terhadap materi yang diberikan guru. Siswa sudah mulai memunculkan dampak positif terhadap rasa ingin tahunya. Ada beberapa siswa yang sudah mulai berani memunculkan pertanyaan ketika guru memberikan kesempatan untuk bertanya. Siswa juga sudah mulai berani mengemukakan pendapat, kritikan mengenai jawaban maupun presentasi yang dilakukan siswa lain di depan kelas. Proses pelaksanaan tersebut sudah dapat menumbuhkan rasa percaya diri siswa, dengan adanya komunikasi yang baik yang terjalin antara guru dengan siswa dan anatar siswa dengan siswa. Hal tersebut menunjukkan bahwa adanya peningkatan dari segi keterampilan berbicara yang dialami siswa.

Nilai rata-rata yang didapatkan siswa secara klasikal juga mengalami peningkatan. Secara klasikal nilai rentang klasikal siswa mencapai 73.67. Hal tersebut juga menjadi bahan evaluasi yang dilakukan peneliti dan guru kelas, khusunya pada proses pelaksanaannya. Nilai rata-rata dan ketuntasan belajar yang didapat siswa memang sudah terlihat adanya peningkatan, tetapi dapat tercapai keberhasilan penelitian. Berdasarkan hasil didapatkan pada tindakan siklus I, guru beserta peneliti perlu melakukan tindakan pada siklus selanjutnya untuk dapat memperbaiki hasil belajar siswa dan dapat mencapai indikator keberhasilan yang diinginkan.

\section{Siklus II}

Berangkat dari evaluasi yang dilakukan peneliti mengenai pelaksanaan tindakan sebelumnya, siklus II ini diharapkan dapat meningkatkan keterampilan siswa dalam berbicara. Proses pelaksanaan yang dilakukan pada siklus II ini masih tiga kali pertemuan dengan waktu 3x35 menit. Pelaksanaan kedua menghasilkan siswa sudah jauh lebih mengerti mengenai penggunaan media gambar pada saat proses pembelajaran berlangsung. Guru juga memberikan media gambar yang berbeda dengan media yang sebelumnya, sehingga siswa menjadi lebih antusias mendengarkan materi dari guru. Penerapan pembelajaran dengan menggunakan media pada siklus II juga menghasilkan dampak yang positif bagi siswa. Siswa sudah banyak yang memberikan 
respons, bahkan pada saat guru memberikan kesempatan pada siswa untuk maju didepan kelas sudah ada banyak mau tanpa ditunjuk. Guru juga memberikan kesempatan bagi siswa yang pada saat pertemuan sebelumnya untuk memberikan pendapat, kritikan, pertanyaan. Antusias siswa dalam bertanya sudah jauh lebih banyak dibandingkan pada tindakan yang sebelumnya. Rasa percaya diri siswa untuk tampil di depan kelas di hadapan siswa yang lain juga sudah mulai meningkat.

Nilai rata-rata yang diperoleh siswa pada pelaksanaan tindakan siklus II mengalami peningkatan menjadi 77.25. Hal tersebut menunjukkan bahwa hasil belajar siswa dalam meningkatkan keterampilan berbicara sudah berjalan jauh lebih baik dari tindakan sebelumnya. Persentase ketuntasan belajar dan nilai-rata-rata yang sudah dipaparkan diatas menunjukkan bahwa tindakan siklus II dapat meningkatkan indikator keberhasilan yang ingin dicapai. Hasil tersebut membuktikan bahwa media tersebut dapat meningkatkan keterampilan berbicara siswa. Hasil tersebut dapat mencapai indikator keberhasilan penelitian yaitu dengan nilai rata-rata 70, sedangkan nilai pada tindakan sudah mencapai 77.25 , hasil ketuntasan belajar $\geq 75 \%$, sedangkan pada pelaksanaan siklus II sudah mencapai $82.41 \%$. Sehingga, penerapan media tersebut terbukti dapat meningkatkan keterampilan berbicara dan sudah tidak memerlukan pelaksanaan untuk siklus selanjutnya.

\section{PEMBAHASAN}

Temuan yang sudah dilaksanakan beberapa peneliti yang terkait dengan meningkatkan keterampilan berbicara menggunakan media gambar seperti kreativitas guru yang meningkat, rasa percaya diri siswa yang muncul, komunikasi yang terjadi antara siswa dengan siswa dan guru dengan siswa menjadi lebih terjalin. (Sudarminah, 2009) memaparkan berdasarkan penelitian yang dilakukan, media gambar yang digunakan untuk meningkatkan berbicara siswa dapat mengubah perilaku siswa setelah mencapai proses belajar dengan menggunakan media pembelajaran, seperti media gambar. Sejalan dengan itu terdapat penelitian menjelaskan bahwa media gambar menjadi media untuk meningkatkan minat keterampilan berbicara siswa, siswa dapat menjadi lebih kreatif dan menarik pada saat proses pembelajaran serta akan menumbuhkan daya tarik bagi siswa untuk mendorong siswa dalam terampil berbicara dan minat dalam menerima materi yang diberikan guru. Hal tersebut terlihat seperti dapat membantu guru dalam lebih mudah menyampaikan materi yang ada pada pembelajaran, dapat lebih menarik siswa dalam belajar, memberikan stimulus untuk meningkatkan minat siswa dalam berbicara. Hal ini menunjukkan bahwa peningkatan yang dapat terlihat dari hasil belajar siswa, nilai rata-rata siswa secara klasikal dan persentase ketuntasan siswa yang dapat mencapai indikator keberhasilan pada penelitian.

Proses pembelajaran dapat membantu perkembangan rasa percaya diri siswa untuk mengurangi rasa takutnya untuk berbicara di depan umum dan ketakutan yang berlebihan akan membuatnya jauh lebih takut akan kematian seperti yang disampaikan (Dwyer \& Davidson, 2012) temuan yang ada pada pelaksanaan tindakan siklus I, di refleksi dengan bekerja sama antara peneliti dan guru kelas untuk memberikan motivasi dan perbaikan pembelajaran agar keterampilan berbicara siswa jauh lebih meningkat dan dapat mencapai indikator keberhasilan sesuai dengan yang ingin dicapai. Sejalan dengan temuan yang didapatkan pada tindakan siklus I, (Sudjana, 2001) menyatakan bahwa kegiatan belajar dengan menggunakan media gambar menjadi salah satu alternatif untuk menarik minat siswa dalam belajar secara jauh lebih efektif. Berdasarkan hal tersebut siswa perlu diberikan perbaikan dalam pembelajaran untuk dapat lebih mengembangkan rasa percaya diri siswa dalam berkomunikasi dengan baik, berimajinasi secara berkembang untuk menjadi dasar terampil dalam berbicara. Terlihat dari perolehan rentang nilai mencapai keberhasilan dan persentase hasil belajar siswa yang memang belum mencapai indikator keberhasilan. Hasil nilai rata-rata siswa secara klasikal 73.67 sedangkan nilai KKM 70. Sedangkat persentase yang didapatkan siswa secara klasikal masih mencapai $60.71 \%$ dengan ketercapaian yang seharusnya ingin dicapai $\geq 75 \%$ siswa yang sudah tuntas. Pembelajaran yang dilakukan untuk mengetahui peningkatan keterampilan berbicara juga dapat di lihat tidak hanya dari penggunaan media namun pelaksanaannya seperti mendongeng selama proses pemeblajaran berlangsung seperti penelitian yang dilakukan (Khoiruddin, 2014).

Tindakan perbaikan yang dilakukan pada siklus II menunjukkan peningkatan yang cukup baik. Siswa pada saat awal pembelajaran sudah mulai memberikan respons yang lebih baik daripada pertemuan sebelumnya. Guru memberikan sedikit ice breaking untuk memotivasi dan melihat siswa siap menerima materi. Antusias siswapun menjadi meningkat pada tujuan tersampaikan masih dengan menggunakan media gambar. Berdasarkan hasil yang didapatkan siswa, pada pelaksanaan siklus II sudah banyak siswa yang memperoleh nilai keterampilan berbicara diatas ketuntasan minimal dan dapat mencapai indikator keberhasilan yang ingin dicapai. Hal ini disebabkan guru sudah memperbaiki kegiatan belajar saat sudah dilakukan pada tindakan siklus I. Perbaikan pembelajaran masih dengan menggunakan media gambar khususnya pada peningkatan keterampilan berbicara siswa dengan lebih meningkatkan aktivitas yang dilakukan siswa dalam berbicara. Kegiatan diskusi dan menceritakan kembali isi cerita masih lebih sering digunakan pada proses pembelajaran, sehingga melatih siswa untuk lebih berani bertanya, berpendapat, memberi kritik dan tanggapan. Fakta yang didapatkan dari penelitian yang dilakukan (Vani \& Vijaya, 2016) sejalan dengan temuan pada penelitian yang dilakukan peneliti bahwasannya keterampilan berbicara pada siswa dapat meningkat jika siswa tersebut mendapat motivasi dan otonomi berbicara dalam konteks yang sudah diberikan.

Peningkatan tersebut dapat membuktikan bahwa penggunaan media gambar siswa dapat terampil bicara. Sejalan dengan itu penelitian yang dilakukan oleh (Rajab, 2015) bahwa kunci dari peningkatan keterampilan berbicara dapat ditingkatkan jika menggunakan model bahan ajar yang baik. Pengunaan model, metode maupun media pada saat pembelajaran akan berpengaruh terhadap efektivitas siswa dalam menerima materi yang diberikan guru. Siswa terlihat jauh lebih aktif selama proses pembelajaran berlangsung, dan suasana kelas terlihat jauh lebih kondusif. 
Berdasarkan hasil penelitian (Sunaryanto, 2015) menyimpulkan terdapat beberapa unsur yang memang dengan menggunakan media gambar dapat meningkatkan keterampilan berbicara seperti kosa kata dan artikulasi siswa. Hal tersebut dapat disimpulkan bahwa peningkatan keterampilan berbicara dengan menggunakan media memang sangat efektif dilakukan pada pembelajaran di dalam kelas. (As, 2016) berpendapat bahwa dengan menggunakan berbicara keterampilan yang dimiliki siswa jauh lebih meningkat jika dibandingkan dengan siswa yang diajarkan hanya secara konvensional. Pengaruh yang didapatkan siswa akan terlihat pada hasil belajarnya baik secara individu maupun secara klasikal.

\section{SIMPULAN}

Hasil kegiatan tentang pelaksanaan kegiatan belajar mengajar memakai media untuk meningkatkan keterampilan berbicara dapat disimpulkan dalam pelaksanaannya sudah cukup baik. Pernyataan tersebut didapatkan dari perlaksanan pembelajaran sudah mampu meningkatkan keterampilan berbicara siswa. Media gambar memiliki dampak positif bagi anak. Guru mendapatkan alternatif dalam memperbaiki permasalahan di kelas. Selain metode maupun model pembelajaran, guru merasa bahwa dengan digunakannya media pembelajaran untuk mendukung pelaksanaan pembelajaran dapat membantu mencapai keberhasilan belajar siswa. Kegiatan pembelajaran denganmenggunakan media gambar memberikan gambaran bahwa siswa jauh lebih antusias dalam menerima materi yang diberikan guru. Siswa terlihat jauh lebih aktif dalam memberikan pendapat, tanggapan maupun pertanyaan mengenai materi yang diterima.

Pemahaman yang dimiliki siswa meningkat dengan penggunaan media gambar selama proses pembelajaran berlangsung. Komunikasi yang terjadi antara guru dan siswa terjalin baik dan suasana kelas menjadi kondusif. Sikap percaya diri yang dimunculkan siswa dalam bereksplorasi di depan kelas juga sudah mulai tampak penggunaan media gambar juga dapat meningkatkan keterampilan berbicara siswa. Hal ini terlihat dengan adanya peningkatan hasil belajar yang dicapai siswa dengan rata-rata secara klasikal mencapai 77.25 dan ketuntasan belajar mencapai $82.14 \%$. Kegiatan ini membuktikan sudah tercapai keberhasilannya pada penelitian ialah rata-rata secara klasikal dan ketuntasan belajar siswa mencapai $\geq 75 \%$ dan KKM mencapai 70 .

Dari hasil simpulan di atas maka dapat disusun saran penelitian sebagai berikut. Bagi guru siswa harus selalu ditingkatkan keterampilan berbicaranya karena dengan terampil berbicara akan memiliki pengaruh kepada hasil maupun ketercapaian dalam proses pembelajaran. Guru harus dapat membangkitkan sikap rasa percaya diri yang dimiliki siswa dengan mencari alternatif pada saat melaksanakan pembelajaran. menggunakan model, metode dan media pembelajaran yang dirasa tepat untuk membuat suasana di kelas menjadi kondusif. Siswa pun menerima materi dengan mudah dan tidak merasa bosan ketika proses pembelajaran berlangsung. Pihak sekolah juga diharapkan memiliki wadah seperti ekstrakurikuler yang dapat mendukung keterampilan berbicara siswa dan siswa pun diarahkan untuk dapat mengikuti ekstrakurikuler tersebut. Peningkatan keterampilan berbicara diharapkan menjadi dasar siswa dapat hidup bermasyarakat dengan baik.

\section{DAFTAR RUJUKAN}

Cullinan, B. (1993). Children's Voices: Talk in the Classroom. Newark,DE: International Reading Association.

Dwyer, K. K., \& Davidson, M. M. (2012). Is Public Speaking Really More Feared Than Death? Communication Research Report, 29(2), 99-107. http://dx.doi.org/10.1080/08824096.2012.667772.

Hedge, T. (2008). Teaching and Learning in the Languange Classroom. Oxford: Oxford University Press.

Kemmis, S., \& MC, T. R. (2014). The Action Research Planner: Doing Critical Participatory Action Research. Springer Singapore Heidelberg. https://doi.org/DOI 10.1007/978-981-4560-67-2

Rajab, T. (2015). An Applied Model of Teaching Materials to Improve Student's Speaking Skill. International Multidisiplinary Journal, 3(1).

Sudarminah, S. (2009). Upaya Peningkatan Pembelajaran Berbicara dengan Model Pembelajaran Gambar Seri untuk Siswa Kelas VIII SMP Negeri 6 Semarang. Media Penelitian Pendidikan: Jurnal Penelitian dalam Bidang Pendidikan dan Pengajaran, 3(2), 45-52.

Sudjana, N. (2001). Metode dan Teknik Pembelajaran Partisipatif. Bandung: Falah Production.

Sunaryanto, M. (2015). Growing The Ability of Speaking for Children 5-6 Years By Adding a Picture at Kindergarten ABA Wonotingal Poncosari Srandakan Bantul. Jurnal Mahasiswa Prodi PG PAUD, 4(4).

Tarigan, G. H. (1992). Berbicara Sebagai Suatu Keterampilan Berbahasa. Bandung: Angkasa.

Tarigan, G. (2015). Berbicara sebagai Suatu Ketarampilan Berbahasa. Bandung: Angkasa.

Vani, V., \& Vijaya. (2016). Enhancing Student's Speaking Skills Through Peer Team Teaching: A Student Centered Approach. Journal I-Manager's on English Language Teaching, 6(4).

Wilson, J. A. (1997). A Program to Develop the Listening and Speaking Skills of Children in a First Grade Classroom. Virginia: University of Virginia.

Zuhriyah, M. (2016). Storytelling to Improve Speaking Skills. English Education: Jurnal Tadris Bahasa Inggris, 7(2), 194-205. 